\title{
Stratospheric Ozone Variations Caused by Solar Proton Events between 1963 and 2005
}

\section{Charles H. Jackman and Eric L. Fleming}

\section{Brief, Popular Summary of the Paper:}

Long-term variations in ozone have been caused by both natural and humankind related processes. In particular, the humankind or anthropogenic influence on ozone from chlorofluorocarbons and halons (chlorine and bromine) has led to international regulations greatly limiting the release of these substances. These anthropogenic effects on ozone are most important in polar regions and have been significant since the 1970s. Certain natural ozone influences are also important in polar regions and are caused by the impact of solar charged particles on the atmosphere. Such natural variations have been studied in order to better quantify the human influence on polar ozone.

Earge-scale explosions on the Sun near solar maximum lead to emissions of charged particles (mainly protons and electrons), some of which enter the Earth's magnetosphere and rain down on the polar regions. "Solar proton events" have been used to describe these phenomena since the protons associated with these solar events sometimes create a significant atmospheric disturbance.

Very large solar proton events occurred in several years and caused very distinctive polar changes in layers of the Earth's atmosphere known as the stratosphere (12-50 km; 7-30 miles) and mesosphere (50-90 km; 30-55 miles). The solar protons created hydrogen- and nitrogen- containing compounds, which led to the polar ozone destruction. The hydrogen-containing compounds have very short lifetimes and lasted for only a few days (typically the duration of the solar proton event). On the other hand, the nitrogen-containing compounds lasted much longer, especially in the Winter. The lifetime of these compounds in Winter can be quite long since winds typically transport these nitrogen-containing constituents from the mesosphere and upper stratosphere to the lower stratosphere, where they can last for months to years depleting ozone over this time period.

The Goddard Space Flight Center two-dimensional (latitude versus altitude) chemistry and transport model was used to study the long-term impact of solar proton events between 1963 and 2005 on stratospheric ozone. The model predicted that the very large solar proton events in 1972, 1989, 2000, 2001 , and 2003 caused total polar ozone depletions of 1-3\%, which lasted for several months to years past the events. These changes are modest compared to the downward trends caused by anthropogenic chlorine and bromine in the polar regions over the 1980-2000 time period [ $3 \% /$ decade in the Northern Hemisphere and $\sim 4-9 \%$ /decade in the Southern Hemisphere], however, they need to be considered in understanding polar changes during particular years. 


\title{
STRATOSPHERIC OZONE VARIATIONS CAUSED BY SOLAR PROTON EVENTS BETWEEN 1963 AND 2005
}

\author{
CHARLES H. JACKMAN \\ Atmospheric Chemistry and Dynamics Branch \\ Code 613.3 \\ NASA Goddard Space Flight Center \\ Greenbelt, MD 20771, U.S.A. \\ (e-mail: Charles.H.Jackman@nasa.gov) \\ ERIC L. FLEMING \\ Atmospheric Chemistry and Dynamics Branch \\ Code 613.3 \\ NASA Goddard Space Flight Center \\ Greenbelt, MD 20771, U.S.A. \\ (e-mail:fleming@kahuna.nasa.gov)
}

\begin{abstract}
Solar proton fluxes have been measured by satellites for over forty years (1963-2005). Several satellites, including the NASA Interplanetary Monitoring Platforms (1963-1993) and the NOAA Geostationary Operational Environmental Satellites (19942005), have been used to compile this long-term dataset. Some solar eruptions lead to solar proton events (SPEs) at the Earth, which typically last a few days. High energy solar protons associated with SPEs precipitate on the Earth's atmosphere and cause increases in odd hydrogen $\left(\mathrm{HO}_{\mathrm{x}}\right)$ and odd nitrogen $\left(\mathrm{NO}_{\mathrm{y}}\right)$ in the polar cap regions $\left(>60^{\circ}\right.$ geomagnetic). The enhanced $\mathrm{HO}_{\mathrm{x}}$ leads to short-lived ozone depletion ( days) due to the short lifetime of $\mathrm{HO}_{\mathrm{x}}$ constituents. The enhanced $\mathrm{NO}_{\mathrm{y}}$ leads to long-lived ozone changes because of the long lifetime of the $\mathrm{NO}_{\mathrm{y}}$ family in the stratosphere and lower mesosphere. Very large SPEs occurred in 1972, 1989, 2000, 2001, and 2003 and were predicted to cause maximum total ozone depletions of $1-3 \%$, which lasted for several months to years past the events. These long-term ozone changes caused by SPEs are discussed below.
\end{abstract}

\section{Introduction}

Explosions on the Sun sometimes result in large fluxes of high-energy solar protons at the Earth, especially near the maximum period of activity of a solar cycle. This disturbed time, wherein the solar proton flux is generally elevated for a few days, is known as a solar proton event (SPE). Solar protons are guided by the Earth's magnetic field and impact both the northern and southern polar cap regions $\left(>60^{\circ}\right.$ geomagnetic latitude), e.g., see Jackman and McPeters (2004). These protons can impact the neutral middle atmosphere (stratosphere and mesosphere) and produce both $\mathrm{HO}_{\mathrm{x}}\left(\mathrm{H}, \mathrm{OH}, \mathrm{HO}_{2}\right)$ and $\mathrm{NO} \mathrm{y}\left(\mathrm{N}, \mathrm{NO}, \mathrm{NO}_{2}, \mathrm{NO}_{3}, \mathrm{~N}_{2} \mathrm{O}_{5}\right.$, $\mathrm{HNO}_{3}, \mathrm{HO}_{2} \mathrm{NO}_{2}, \mathrm{ClONO}_{2}, \mathrm{BrONO}_{2}$ ) constituents either directly or through a photochemical sequence (e.g., Swider and Keneshea, 1973; Crutzen et al., 1975; Jackman et al., 1980; Solomon et al., 1981; McPeters, 1986; Zadorozhny et al., 1992). Ozone is also impacted by the solar protons through direct photochemical destruction forced by the $\mathrm{HO}_{\mathrm{x}}$ and $\mathrm{NO}_{\mathrm{y}}$ enhancements (e.g., Weeks et al., 1972; Heath et al., 1977; Solomon et al., 1983; Jackman et al., 1990).

Although all sizes of SPEs can have an impact on the atmosphere, the extremely large SPEs cause the most pronounced changes. Several of these extremely large SPEs have occurred in the past forty years. Huge fluxes of high-energy protons have impacted the Earth's atmosphere in 1972, 1989, 2000, 2001, and 2003. The impact of SPEs over the 1963-2005 period will be discussed, concentrating particularly on the atmospheric effects during and after the huge SPEs. 
The paper is divided into six primary sections, including the Introduction. We discuss the very important solar proton measurements and their production of odd hydrogen $\left(\mathrm{HO}_{\mathrm{x}}\right)$ and odd nitrogen $\left(\mathrm{NO}_{\mathrm{y}}\right)$ in section 2. A comparison of the largest fifteen SPEs in the past four solar cycles is also undertaken in section 2. The GSFC two-dimensional model used to simulate the impact of the SPEs on the atmosphere is discussed in section 3. The short-term impact of these SPEs on ozone during and for several days after particular events is given in section 4 . Longer term influences of the SPEs on the middle atmosphere are discussed in section 5. Finally, the conclusions are given in section 6.

\section{Proton Fluxes; Odd Hydrogen $\left(\mathrm{HO}_{x}\right)$ and Odd Nitrogen $\left(\mathrm{NO}_{y}\right)$ Production}

\subsection{PROTON FLUXES}

Solar proton fluxes have been measured by a number of satellites in interplanetary space or in orbit around the Earth. The National Aeronautics and Space Administration (NASA) Interplanetary Monitoring Platform (IMP) series of satellites provided measurements of proton fluxes from 1963-1993. IMPs 1-7 were used for the fluxes from 1963-1973 (Jackman et al., 1990) and IMP 8 was used for the fluxes from 1974-1993 (Vitt and Jackman, 1996). The National Oceanic and Atmospheric Administration (NOAA) Geostationary Operational Environmental Satellites (GOES) were used for proton fluxes from 1994-2005 (Jackman et al., 2005a).

Protons in their energy deposition process cause ionizations, dissociations, predissociations, and dissociative ionizations in collisions with atmospheric constituents. The protons thus produce secondary electrons, ions, excited molecules and atoms. The proton fluxes were used to compute daily average ion pair production profiles using an energy deposition scheme first discussed in Jackman et al. (1980). The scheme includes the deposition of energy by the protons and assumes $35 \mathrm{eV}$ are required to produce one ion pair (Porter et al., 1976). Thereby, a dataset of daily average ion pair production rates for the period 19632005 were created for use in model studies.

\subsection{ODD HYDROGEN (HOX) PRODUCTION}

Along with the ion pairs, the protons and their associated secondary electrons also produce odd hydrogen $\left(\mathrm{HO}_{\mathrm{x}}\right)$. The production of $\mathrm{HO}_{\mathrm{x}}$ relies on complicated ion chemistry that takes place after the initial formation of ion pairs (Swider and Keneshea, 1973; Frederick, 1976; Solomon et al. 1981). Solomon et al. (1981) computed $\mathrm{HO}_{\mathbf{x}}$ production rates as a function of altitude and ion pair production. Each ion pair typically results in the production of around two $\mathrm{HO}_{\mathrm{x}}$ constituents in the upper stratosphere and lower mesosphere. In the middle and upper mesosphere, an ion pair is computed to produce less than two $\mathrm{HO}_{\mathrm{x}}$ constituents per ion pair. We include the $\mathrm{HO}_{\mathrm{x}}$ production by SPEs in our model using a look-up table (see Jackman et al., 2005b) invoking the computations of Solomon et al. (1981). The $\mathrm{HO}_{\mathrm{x}}$ constituents have lifetimes of only hours in the middle atmosphere, therefore, any further effects on other constituents from the $\mathrm{HO}_{\mathrm{x}}$ group are apparent only during and shortly after an SPE. 


\subsection{ODD NITROGEN (NOY) PRODUCTION}

Odd nitrogen is produced when the energetic charged particles (protons and associated secondary electrons) collide with and dissociate $\mathrm{N}_{2}$. Following Porter et al. (1976) it is assumed that $\sim 1.25 \mathrm{~N}$ atoms are produced per ion pair. The Porter et al. (1976) study also further divided the proton impact of $\mathrm{N}$ atom production between ground state ( $\sim 45 \%$ or $\sim 0.55$ per ion pair) and excited state ( $\sim 55 \%$ or $\sim 0.7$ per ion pair) nitrogen atoms. Ground state $\left[\mathrm{N}\left({ }^{4} \mathrm{~S}\right)\right]$ nitrogen atoms can create other $\mathrm{NO}_{\mathrm{y}}$ constituents, such as $\mathrm{NO}$, through

$$
\mathrm{N}\left({ }^{4} \mathrm{~S}\right)+\mathrm{O}_{2} \diamond \mathrm{NO}+\mathrm{O}
$$

or can lead to $\mathrm{NO}_{\mathrm{y}}$ destruction through

$$
\mathrm{N}\left({ }^{4} \mathrm{~S}\right)+\mathrm{NO} \diamond \mathrm{N}_{2}+\mathrm{O} \text {. }
$$

Generally, excited states of atomic nitrogen, such as $N\left({ }^{2} D\right)$, result in the production of NO through

$$
\mathrm{N}\left({ }^{2} \mathrm{D}\right)+\mathrm{O}_{2} \diamond \mathrm{NO}+\mathrm{O}
$$

(e.g., Rusch et al., 1981; Rees, 1989) and do not cause significant destruction of $\mathrm{NO}_{\mathrm{y}}$. Rusch et al. (1981) showed that there are huge differences in the final results of model computations of $\mathrm{NO}_{\mathrm{y}}$ enhancements from SPEs that depend strongly on the branching ratios of the $\mathrm{N}$ atoms produced. We currently do not include any of the excited states of atomic nitrogen [e.g., $N\left({ }^{2} \mathrm{D}\right), \mathrm{N}\left({ }^{2} \mathrm{P}\right)$, and $\left.\mathrm{N}^{\dagger}\right]$ as computed constituents in our mødel. We use the following fairly accurate way to best represent the production of $\mathrm{NO}_{\mathrm{y}}$ constituents by the SPEs: Assume that $45 \%$ of the $\mathrm{N}$ atoms produced per ion pair result in the production of $\left.\mathrm{N}^{4} \mathrm{~S}\right)$ $\{\sim 0.55$ per ion pair $\}$ and that $55 \%$ of the $\mathrm{N}$ atoms produced per ion pair result in the production of NO $\{\sim 0.7$ per ion pair $\}$.

The lifetime of odd nitrogen can vary dramatically depending on season and altitude. Odd nitrogen has a relatively short lifetime ( days) in the sunlit middle and upper mesosphere, however, lower mesospheric and stratospheric $\mathrm{NO}_{\mathrm{y}}$ can last for weeks past an SPE. A large portion of the SPE-produced $\mathrm{NO}_{\mathrm{y}}$ is conserved in a mostly dark polar middle atmosphere in the late fall and winter. This $\mathrm{NO}_{\mathrm{y}}$ can then be transported to lower altitudes via the general downward flowing winds during this time of year and its lifetime can range from months to years, if transported all the way to the middle and lower stratosphere.

We have quantified middle atmospheric $\mathrm{NO}_{\mathrm{y}}$ production previously (Jackman et al., 1990; Vitt and Jackman, 1996; Jackman et al., 2005a) for years 1963 through 2003. We add $\mathrm{NO}_{\mathrm{y}}$ computations in this study to these earlier calculations for years 2004 and 2005 and present the annual production from SPEs for the 43-year period 1963 through 2005 in Figure 1. The annual-averaged sunspot number is also shown in Figure 1 to illustrate the rough correlation between solar maximum periods and frequency of SPEs. 


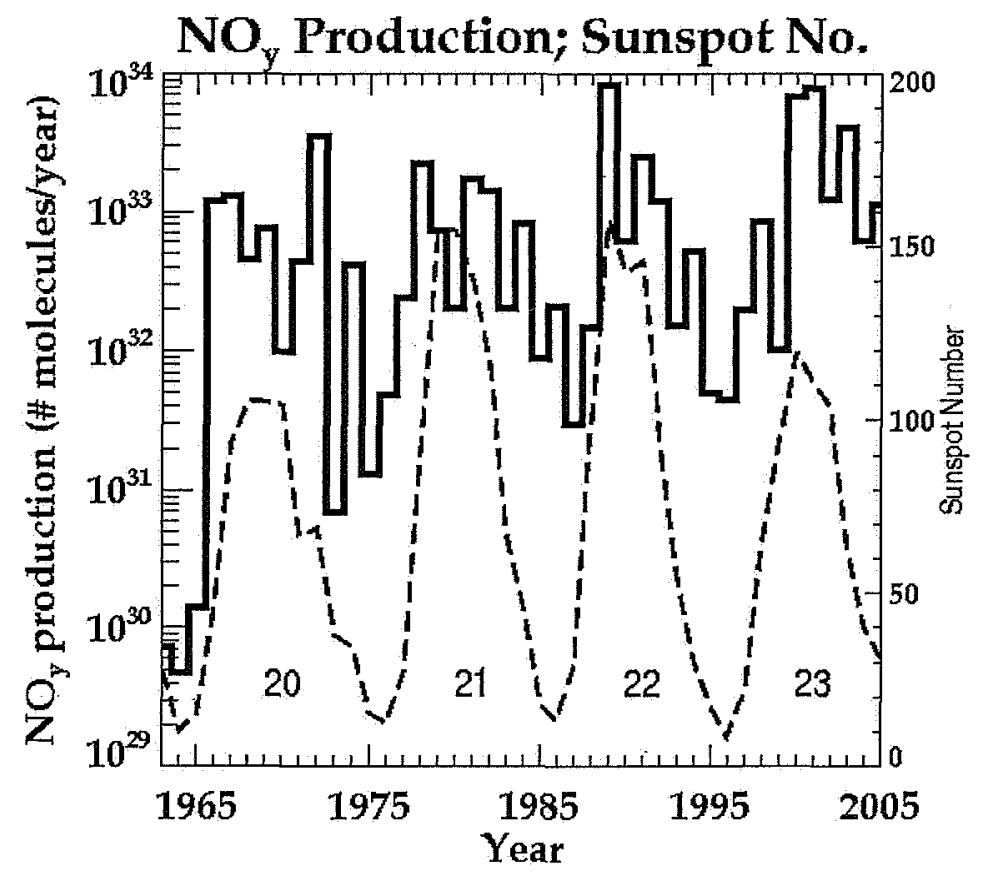

Figure 1. Total number of $\mathrm{NO}_{\mathrm{y}}$ molecules produced per year in the polar stratosphere and mesosphere by SPEs (solid histogram- left ordinate) and annually-averaged sunspot number (dashed line - right ordinate) for years 1963 through 2005 .

Substantial amounts of $\mathrm{NO}_{\mathrm{y}}$ were produced near solar maximum in several years. The annual global $\mathrm{NO}_{\mathrm{y}}$ production from solar protons is computed to be 3.7, 8.4, 6.7, 7.9, and $4.1 \times 10^{33}$ molecules for the very active years $1972,1989,2000,2001$, and 2003 , respectively. These annual production rates from SPEs can be compared with the largest global $\mathrm{NO}_{\mathrm{y}}$ source \{nitrous oxide oxidation, $\mathrm{N}_{2} \mathrm{O}+\mathrm{O}\left({ }^{1} \mathrm{D}\right)$ \} of about $3.3 \times 10^{34}$ molecules/year (Vitt and Jackman, 1996). The SPE sources of $\mathrm{NO}_{\mathrm{y}}$ were very significant during these particular years for the middle atmosphere. Since the SPEs typically last only a few days, these impulses of $\mathrm{NO}_{\mathrm{y}}$ from SPEs can impact the polar odd nitrogen amounts substantially during brief periods.

The fifteen largest SPEs based on $\mathrm{NO}_{\mathrm{y}}$ production in the past 40 years are given in Table 1. Surprisingly, eight of them occurred in the most recent solar maximum period.

Table 1. Largest fifteen solar proton events in the past forty years.

\begin{tabular}{ccc}
\hline Date of SPEs & Rank in size & $\begin{array}{c}\text { NO } \text { production } \\
\text { in the middle atmosphere } \\
\text { (\# of 103 }\end{array}$ \\
\hline October 19-27, 1989 & 1 & 6.7 \\
August 2-10, 1972 & 2 & 3.6 \\
July 14-16, 2000 & 3 & 3.5 \\
October 28-31, 2003 & 4 & 3.4 \\
November 5-7, 2001 & 5 & 3.2 \\
November 9-11,2000 & 6 & 2.3 \\
September 24-30, 2001 & 7 & 2.0 \\
August 13-26, 1989 & 8 & 1.8 \\
November 23-25, 2001 & 9 & 1.7 \\
September 2-7, 1966 & 10 & 1.2 \\
January 15-23, 2005 & 11 & 1.1 \\
Sep. 29-Oct. 3, 1989 & 12 & 1.0 \\
Jan. 28-Feb. 1, 1967 & 13 & 0.99 \\
March 23-29, 1991 & 14 & 0.89 \\
September 7-17, 2005 & 15 & 0.88 \\
\hline
\end{tabular}




\section{GSFC Two-dimensional Model Description and Simulations}

The latest version of the Goddard Space Flight Center (GSFC) two-dimensional (2D) atmospheric model was used to predict atmospheric changes caused by the solar protons. The model has been in use since the late 1980's and has undergone extensive improvements over the years (Douglass et al., 1989; Jackman et al., 1990). The vertical range of the model, equally spaced in log pressure, is from the ground to approximately $90 \mathrm{~km}(0.0024 \mathrm{hPa})$ with approximately a $2 \mathrm{~km}$ grid spacing. Latitudes range from $85^{\circ} \mathrm{S}$ to $85^{\circ} \mathrm{N}$ with a $10^{\circ}$ grid spacing.

Fleming et al. (2002) described the methodology to compute the transport for the GSFC 2D model using the global winds and temperatures from meteorological data for particular years. This technique has now been applied using the National Centers for Environmental Prediction - National Center for Atmospheric Research (NCEP-NCAR) reanalysis-2 project (e.g., Kanamitsu et al., 2002). These data cover the time period 1958-present, and extend from the surface to $10 \mathrm{hPa}$. We have used the original NCEP analyses data (Gelman et al., 1986) for 10 to $1 \mathrm{hPa}$ for 1979-present (climatological fields are used above $10 \mathrm{hPa}$ prior to 1979). For the mesosphere for $1-0.002 \mathrm{hPa}$, we employ the temperature measurements made by the Microwave Limb Sounder (MLS) onboard UARS for September 1991 through June 1997 (Wu et al., 2003). The 2D model residual circulation and horizontal and vertical eddy diffusion quantities are then derived following the methodology described in Fleming et al. $(2002,2006)$.

The photochemical scheme includes all reactions that are thought to be important for ozone. The reaction rates, including heterogeneous rates, are taken from Sander et al. (2003). A lookup table is employed in computing the photolytic source term, which is then used in computation of photodissociation rates for atmospheric constituents (Jackman et al., 1996). The GSFC 2D chemistry solver uses the Atmospheric Environmental Research (AER) 2D model scheme (Weisenstein et al., 2004), which computes a diurnal cycle every day. The ground boundary conditions for the source gases are taken from WMO (2003) for the particular simulated year. The model uses chemical families and computes 55 constituents (Jackman et al. 2005b).

We used the GSFC 2D model to compute two primary simulations, "base" and "perturbed," for the years 1960 through 2010. The transport for years 1960-2004 is driven by NCEP products for those particular years, whereas the transport for the individual years 2005-2010 is an average climatology of the 1958-2004 period. The "base" simulation includes no SPEs, whereas the "perturbed" simulation includes all SPEs from January 1, 1963 through December 31, 2005. The perturbation to the atmosphere was caused by the SPE-produced $\mathrm{HO}_{\mathrm{x}}$ and $\mathrm{NO}_{\mathrm{y}}$ enhancement.

\section{Short-term Impact on Ozone}

The ozone response due to very large SPEs is not subtle and has been observed due to numerous events to date (e.g., Jackman and McPeters, 2004; López-Puertas et al. 2005; Seppälä et al. 2006). Ozone within the polar caps $\left(60-90^{\circ} \mathrm{S}\right.$ or $60-90^{\circ} \mathrm{N}$ geomagnetic) is generally depleted to some extent in the mesosphere and upper stratosphere (e.g., Jackman et al. 2005b) within hours of the start of the SPE. Decreases in mesospheric and upper stratospheric ozone are mostly caused by SPE-induced $\mathrm{HO}_{\mathrm{x}}$ increases (see Solomon et al. 1981, 1983; Jackman and McPeters 1985; Jackman et al., 2005b) and last only during and for a few 
hours after the SPEs. SPE-caused $\mathrm{NO}_{\mathrm{y}}$ enhancements can also drive upper stratospheric ozone depletion, but do not cause significant mesospheric ozone depletion (Jackman et al., 2001). Although these short-term SPE impacts on ozone merit study and have helped test atmospheric models (e.g., Jackman and McPeters, 1987), the longer-term SPE impacts on ozone are the more important component in polar stratospheric ozone variation and will be discussed in the next section.

\section{Long-term Impact on Ozone}

The longer-term impact of SPE-induced $\mathrm{NO}_{\mathrm{y}}$ enhancements on ozone has been known for about 30 years. Heath et al. (1977) showed large stratospheric ozone reductions in Nimbus-4 BUV instrument data up to 19 days past the August 1972 events, which were probably caused by the $\mathrm{NO}_{\mathrm{y}}$ enhancements. Several other papers (e.g. Reagan et al., 1981; Solomon and Crutzen, 1981; Rusch et al., 1981; Jackman et al., 1990, $1995,2000,2005 \mathrm{a})$ studied various aspects of $\mathrm{NO}_{\mathrm{y}}$ influence on stratospheric ozone. The primary catalytic cycle for $\mathrm{NO}_{\mathrm{y}}$ destruction of ozone is

$$
\begin{aligned}
& \mathrm{NO}+\mathrm{O}_{3} \diamond \mathrm{NO}_{2}+\mathrm{O}_{2} \\
& \mathrm{NO}_{2}+\mathrm{O} \diamond \mathrm{NO}+\mathrm{O}_{2}
\end{aligned}
$$

Net: $\mathrm{O}_{3}+\mathrm{O} \diamond \mathrm{O}_{2}+\mathrm{O}_{2}$

The long lifetime of the $\mathrm{NO}_{\mathrm{y}}$ constituents allows the influence on ozone to last for a number of months to years past the event. Figure 2 shows the model predicted temporal behavior of profile ozone (lower plot) and $\mathrm{NO}_{\mathrm{y}}$ (upper plot) for the polarmost Northern Hemisphere area $\left(70^{\circ}-90^{\circ} \mathrm{N}\right)$ for the time period $1963-$ 2010. $\mathrm{NO}_{\mathrm{y}}$ shows enhancements between 1 and about $10 \%$ in the lower stratosphere (below $10 \mathrm{hPa}$ ) for particular years. These very large SPEs in a) August 1972; b) August-September-October 1989; and c) July and November 2000, September and November 2001, October 2003, and January and September 2005 cause the $\mathrm{NO}_{\mathrm{y}}$ increases in years a) 1972-3; b) 1989-93; and c) 2000-6, respectively.

The increased $\mathrm{NO}_{\mathrm{y}}$ led to a northern polar stratospheric ozone depletion for extended periods. SPEcaused depletions greater than 3\% are highlighted in "dark gray" in Figure 2 (lower plot). The polar Southern Hemisphere shows similar behavior (not shown), however, there are differences caused by the seasonal differences for the occurrence of the SPEs (e.g., see discussion in Jackman et al. 2005b). SPEs that occur in the late fall/winter time period experience a lower amount of sunlight thus the loss process for $\mathrm{NO}_{\mathrm{y}}$ via

$$
\mathrm{NO}+\mathrm{h} \_(<191 \mathrm{~nm}) \diamond \mathrm{N}+\mathrm{O}
$$

followed by

$$
\mathrm{N}+\mathrm{NO} \Delta \mathrm{N}_{2}+\mathrm{O}
$$

is minimal. The vertical winds are generally downward at this time of year and $\mathrm{NO}_{\mathrm{y}}$ is transported to lower altitudes, where photochemical loss is even less. SPEs in October 1989, November 2000, November 2001, October 2003, and January 2005 are thus quite important in the Northern Hemisphere.

Enhanced levels of $\mathrm{NO}_{\mathrm{y}}$ can also lead to ozone increases (Jackman et al., 2000). This is especially true in years of enhanced halogen loading. The ozone loss rate due to chlorine and bromine can be reduced through reactions such as

$$
\mathrm{ClO}+\mathrm{NO}_{2}+\mathrm{M} \diamond \mathrm{ClONO}_{2}+\mathrm{M}
$$


and $\mathrm{BrO}+\mathrm{NO}_{2}+\mathrm{M} \diamond \mathrm{BrONO}_{2}+\mathrm{M}$

(10),

where chlorine and bromine reservoir constituents $\left(\mathrm{ClONO}_{2}\right.$ and $\left.\mathrm{BrONO}_{2}\right)$ are produced at the expense of the ozone-reducing radicals ( $\mathrm{ClO}$ and $\mathrm{BrO})$.

Although such interference is relatively small in the NH with computed ozone increases of just over $+0.3 \%$ at most, the average altitude of the $0.0 \%$ contour line gradually rises upwards from $\sim 12 \mathrm{~km}$ in 1980 to $\sim 15 \mathrm{~km}$ in 2000 as the effective equivalent stratospheric chlorine increases from 1.8 to $3.2 \mathrm{ppbv}$ over the same time period (see Figure 1-23 of WMO, 2003).
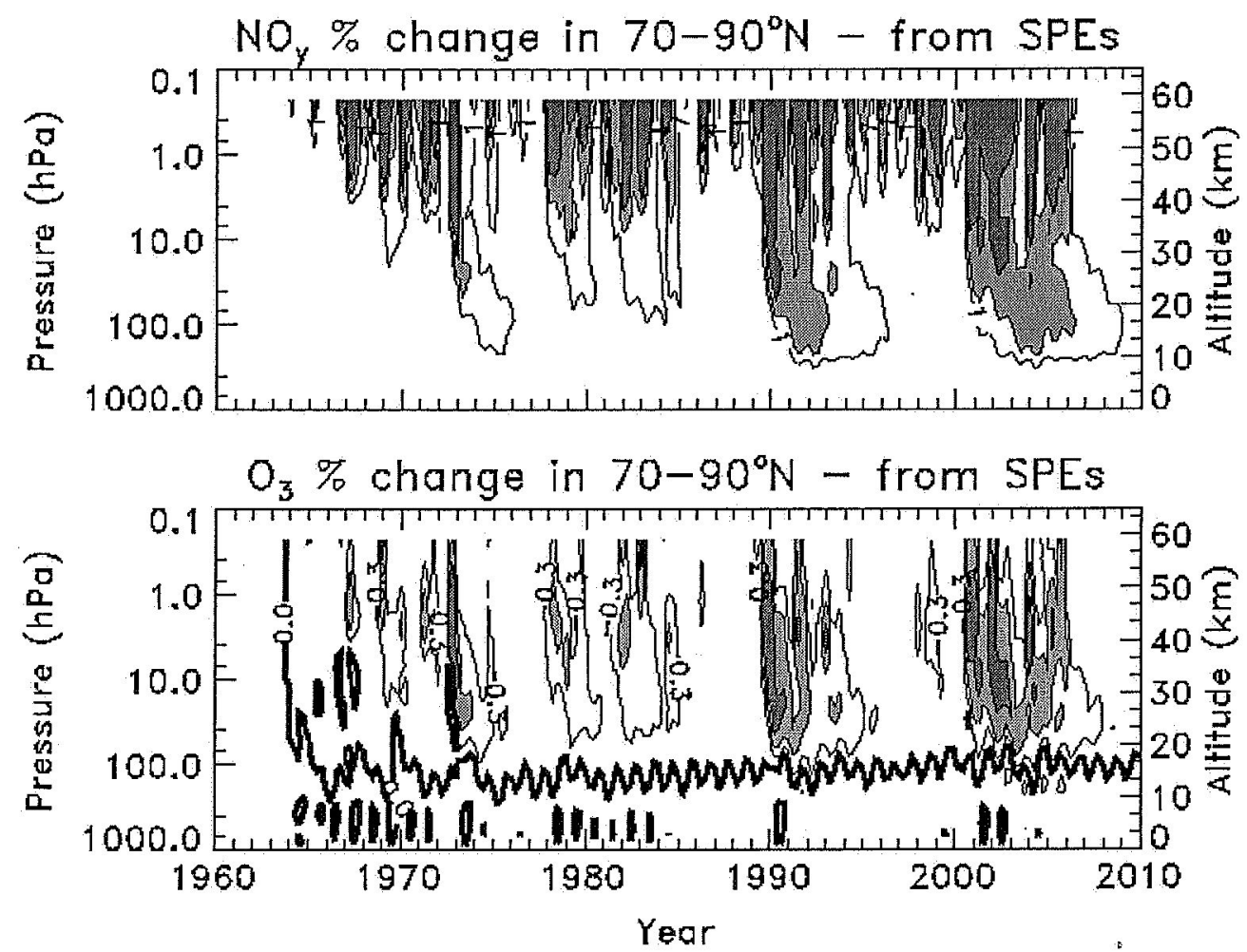

Figure 2. Model computed percentage changes in $\mathrm{NO}_{\mathrm{y}}$ and $\mathrm{O}_{3}$ for the polar Northern Hemisphere area (70$90^{\circ} \mathrm{N}$ ) for 1963-2010 resulting from SPEs in 1963-2005. Contour levels for $\mathrm{NO}_{\mathrm{y}}$ (top plot) are $+1 \%,+3 \%$, and $+10 \%$. The "light gray" and "dark gray" highlighted areas for $\mathrm{NO}_{\mathrm{y}}$ indicate increases from $3 \%$ to $10 \%$ and $>10 \%$, respectively. Contour levels for $\mathrm{O}_{3}$ (bottom plot) are $-3 \%,-1 \%,-0.3 \%, 0 \%$, and $+0.3 \%$. The "light gray" and "dark gray" highlighted areas for $\mathrm{O}_{3}$ indicate decreases from $1 \%$ to $3 \%$ and $>3 \%$, respectively. These changes were computed by comparing the "perturbed" to the "base" simulation.

The impact on total ozone is shown in Figure 3. Both hemispheres had extended periods of depleted ozone from 1-3\% in 1972, 1989-90, and 2000-3. These changes are modest compared to the downward trends caused by halogen loading in the polar regions over the 1980-2000 time period [ $3 \% /$ decade in the $\mathrm{NH}$ and $~ 4-9 \% /$ decade in the SH, WMO (2003)], however, they need to be considered in understanding polar changes during particular years. 


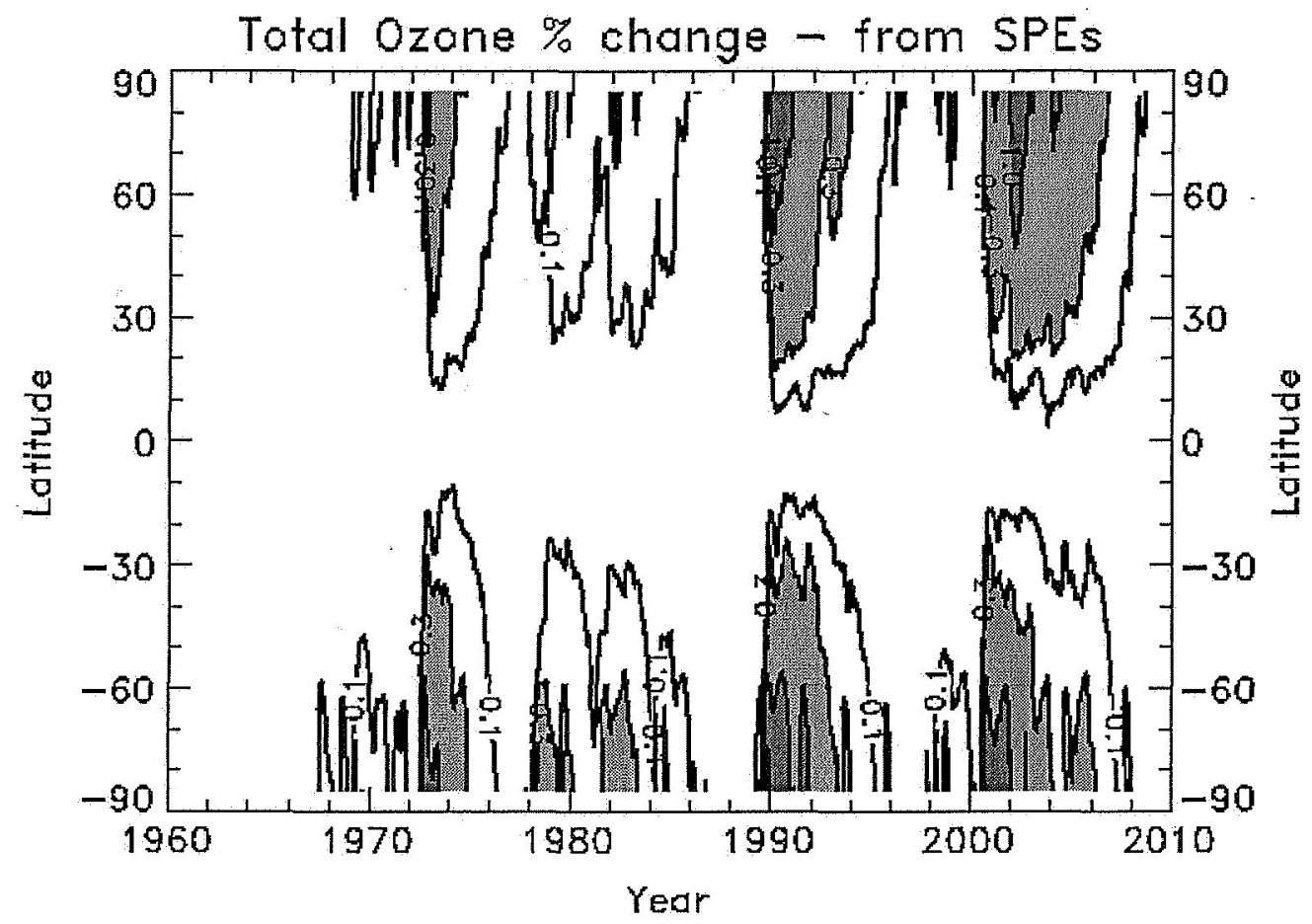

Figure 3. Model computed percentage total ozone changes for 1963-2010 resulting from SPEs in 19632005. Contour intervals are $-1 \%,-0.3 \%$, and $-0.1 \%$. The "light gray" and "dark gray" highlighted areas for indicate decreases from $0.3 \%$ to $1 \%$ and $>1 \%$, respectively. These changes were computed by comparing the "perturbed" to the "base" simulation.

\section{Conclusions}

Several very large SPEs have occurred over the 43-year time period 1963-2005. These events, which occurred in 1972, 1989, 2000, 2001, and 2003, have led to significant polar enhancements in $\mathrm{HO}_{\mathrm{x}}$ and $\mathrm{NO}_{\mathrm{y}}$. The $\mathrm{HO}_{\mathrm{x}}$ enhancements led to short-term mesospheric and upper stratospheric ozone decreases, whereas the $\mathrm{NO}_{\mathrm{y}}$ enhancements led to polar total ozone depletions of 1-3\% lasting several months to years past the events. The $\mathrm{NO}_{\mathrm{y}}$ enhancements were also found to lead to small ozone enhancements in the lowermost stratosphere because of interference with the ozone loss cycles for the chlorine and bromine constituents.

Acknowledgments: This work was supported by the NASA Living With a Star Targeted Research and Technology Program and the NASA Atmospheric Composition Data and Analysis Program. We thank the Interplanetary Monitoring Platform and NOAA Geostationary Operational Environmental Satellite teams for providing the solar proton flux data. 


\section{References}

Crutzen, P. J., I. S. A. Isaksen, and G. C. Reid (1975) Solar proton events: Stratospheric sources of nitric oxide, Science, 189, 457-458.

Douglass, A. R., C. H. Jackman, and R. S. Stolarski (1989) Comparison of model results transporting the odd nitrogen family with results transporting separate odd nitrogen species, J. Geophys. Res., 94, 9862-9872.

Fleming, E. L., C. H. Jackman, J. E. Rosenfield, and D. B. Considine (2002) Two-dimensional model simulations of the QBO in ozone and tracers in the tropical stratosphere, J. Geophys. Res., 107(D23), 4665, doi:10.1029/2001JD001146.

Fleming, E. L., C. H. Jackman, D. K. Weisenstein; and M. K. W. Ko, (2006) The impact of interannual variability on multi-decadal total ozone simulations, submitted to J. Geophys. Res.

Frederick, J. E. (1976) Solar corpuscular emission and neutral chemistry in the Earth's middle atmosphere, J. Geophys. Res., 81, 31793186.

Gelman, M. E., A. J. Miller, K. W. Jihnson, and R. N. Nagatani (1986) Detection of long term trends in global stratospheric temperature from NMC analyses derived from NOAA satellite data, Adv. Space. Res., 6, 17-26.

Heath, D. F., A. J. Krueger, and P. J. Crutzen (1977) Solar proton event: influence on stratospheric ozone, Science, 197, 886-889.

Jackman, C. H., and R. D. McPeters (1985) The response of ozone to solar proton events during solar cycle 21: A theoretical interpretation, J. Geophys. Res., 90, 7955-7966.

Jackman, C. H., and R. D. McPeters (1987) Solar proton events as tests for the fidelity of middle atmosphere models, Physica Scripta, T18, 309-316.

Jackman, C. H., and R. D. McPeters (2004) The effect of solar proton events on ozone and other constituents, in Solar Variability and Its Effects on Climate, edited by J. M. Pap and P. Fox, Geophys. Monograph 141, Washington, DC, pp. 305-319.

Jackman, C. H., J. E. Frederick, and R. S. Stolarski (1980) Production of odd nitrogen in the stratosphere and mesosphere: An intercomparison of source strengths, J. Geophys. Res., 85, 7495-7505.

Jackman, C. H., A. R. Douglass, R. B. Rood, R. D. McPeters, and P. E. Meade (1990) Effect of solar proton events on the middle atmosphere during the past two solar cycles as computed using a two-dimensional model, J. Geophys. Res., 95, 7417-7428.

Jackman, C. H., M. C. Cerniglia, J. E. Nielsen, D. J. Allen, J. M. Zawodny, R. D. McPeters, A. R. Douglass, J. E. Rosenfield, and R. B. Rood (1995) Two-dimensional and three-dimensional model simulations, measurements, and interpretation of the influence of the October 1989 solar proton events on the middle atmosphere, J. Geophys. Res., 100, 11,641-11,660.

Jackman, C. H., E. L. Fleming, S. Chandra, D. B. Considine, and J. E. Rosenfield (1996) Past, present and future modeled ozone trends with comparisons to observed trends, J. Geophys. Res., 101, 28,753-28,767.

Jackman, C. H., E. L. Fleming, and F. M. Vitt (2000) Influence of extremely large solar proton events in a changing stratosphere; $J$. Geophys. Res., 105, 11659-11670.

Jackman, C. H., R. D. McPeters, G. J. Labow, E. L. Fleming, C. J. Praderas, and J. M. Russell (2001) Northern hemisphere atmospheric effects due to the July 2000 solar proton event, Geophys. Res. Lett., 28, 2883-2886.

Jackman, C. H., M. T. DeLand, G. J. Labow, E. L. Fleming, D. K. Weisenstein, M. K. W. Ko, M. Sinnhuber, J. Anderson, and J. M. Russell (2005a) The influence of the several very large solar events in years 2000-2003 on the neutral middle atmosphere, $A d v$. Space Res., 35, 445-450.

Jackman, C. H., M. T. DeLand, G. J. Labow, E. L. Fleming, D. K. Weisenstein, M. K. W. Ko, M. Sinnhuber, and James M. Russell (2005b) Neutral atmospheric influences of the solar proton events in October-November 2003, J. Geophys. Res., 110, A09S27, doi: 10.1029/2004JA010888.

Kanamitsu, M., W. Ebisuzaki, J. Woollen, S.-K. Yang, J. J. Hnilo, M. Fiorino, and G. L. Potter (2002) NCEP-DOE AMIP-II Reanalysis (R-2), Bull. Amer. Meteor. Soc., 83, 1631-1643.

López-Puertas, M., B. Funke, S. Gil-López, T. von Clarmann, G.P. Stiller, M. Höpfner, S. Kellman, H. Fischer, and C.H. Jackman (2005a) Observation of $\mathrm{NO}_{\mathrm{X}}$ enhancement and ozone depletion in the Northern and Southern Hemispheres after the OctoberNovember 2003 solar proton events, J. Geophys. Res., 110, A09S43, doi: 10.1029/2005JA011050.

McPeters, R. D. (1986) A nitric oxide increase observed following the July 1982 solar proton event, Geophys. Res. Lett., 13, 667-670.

Porter, H. S., C. H. Jackman, and A. E. S. Green (1976) Efficiencies for production of atomic nitrogen and oxygen by relativistic proton impact in air, J. Chem. Phys., 65, 154-167.

Reagan, J. B., R. E. Meyerott, R. W. Nightingale, R. C. Gunton, R. G. Johnson, J. E. Evans, W. L. Imhof, D. F. Heath, and A. J. Krueger (1981) Effects of the August 1972 solar particle events on stratospheric ozone, J. Geophys. Res., 86, 1473-1494.

Rees, M. H.(1989) Physics and chemistry of the upper atmosphere, pp. 278-281, Cambridge University Press, Cambridge.

Rusch, D. W., J.-C. Gerard, S. Solomon, P. J. Crutzen, and G. C. Reid (1981) The effect of particle precipitation events on the neutral and ion chemistry of the middle atmosphere, 1, Odd nitrogen, Planet. Space Sci., 29, 767-774.

Sander, S. P., et al. (2003) Chemical kinetics and photochemical data for use in atmospheric studies, JPL Publication 02-25.

Seppälä, A., P.T. Verronen, V.F. Sofieva, J. Tamminen, E. Kyrölä, C.J. Rodger, and M.A. Clilverd (2006) Destruction of the tertiary ozone maximum during a solar proton event, Geophys. Res. Lett., 33, L07804, doi: 10.1029/2005GL025571.

Solomon, S., and P. J. Crutzen (1981) Analysis of the August 1972 solar proton event including chlorine chemistry, J. Geophys. Res., $86,1140-1146$

Solomon, S., D. W. Rusch, J.-C. Gerard, G. C. Reid, and P. J. Crutzen (1981) The effect of particle precipitation events on the neutral and ion chemistry of the middle atmosphere, 2, Odd hydrogen, Planet. Space Sci., 29, 885-892.

Solomon, S., G. C. Reid, D. W. Rusch, and R. J. Thomas (1983) Mesospheric ozone depletion during the solar proton event of July 13 , 1982, 2, Comparison between theory and measurements, Geophys. Res. Lett., 10, $257-260$.

Swider, W., and T. J. Keneshea (1973) Decrease of ozone and atomic oxygen in the lower mesosphere during a PCA event, Planet. Space Sci., 2l, 1969-1973.

Vitt, F. M., and C. H. Jackman (1996) A comparison of sources of odd nitrogen production from 1974 through 1993 in the Earth's middle atmosphere as calculated using a two-dimensional model, J. Geophys. Res., 101, 6729-6739.

Weeks, L. H., R. S. CuiKay, and J. R. Corbin (1972) Ozone measurements in the mesosphere during the solar proton event of 2 November 1969, J. Atmos. Sci., 29, 1138-1142.

Weisenstein, D. K., J. Eluszkiewicz, M. K. W. Ko, C. J. Scott, C. H. Jackman, E. L. Fleming, D. B. Considine, D. E. Kinnison, P. S. Connell, and D. A. Rotman (2004) Separating chemistry and transport effects in 2-D models, $J$. Geophys. Res., 109, D18310, doi: 10.1029/2004JD004744.

World Meteorological Organization (WMO) (2003) Scientific Assessment of Ozone Depletion: 2002, Rep. 47, Global Ozone Res. and Monit. Proj., Geneva.

Wu, D. L., et al. (2003) Mesospheric temperature fro UARS MLS: retrieval and validation, J. Atmos. Sol.-Terr. Phys., 65, $245-267$. 
Zadorozhny, A. M., G. A. Tuchkov, V. N. Kikhtenko, J. Lastovicka, J. Boska, and A. Novak (1992) Nitric oxide and lower ionosphere quantities during solar particle events of October 1989 after rocket and ground-based measurements, J. Atmos. Terr. Phys., 54, 183-192. 